\title{
Implementasi Manajemen Diri Mahasiswa dalam Pendidikan Islam
}

\author{
Hanum Jazimah \\ SMA N 1 Grabag, Kab. Magelang \\ Email: Jazi@yahoo.co.id
}

\begin{abstract}
Abstrak
Manajemen diri berarti menempatkan segala sesuatu secara teratur dalam hidup, dalam penggunaan waktu, pilihan, kepentingan, kegiatan, serta dalam keseimbangan fisik dan mental. Ini juga berarti mendorong diri untuk maju, mengatur semua unsur pribadi, mengendalikan potensi kemauan untuk mencapai hal-hal yang baik, dan mengembangkan berbagai aspek kehidupan pribadi untuk membuatnya lebih sempurna. Syarat pertama untuk semua mahasiswa untuk mencapai tujuan pendidikan mereka adalah motivasi diri. Kedua, organisasi diri, menyiapkan sebaik mungkin terhadap pikiran, tenaga, waktu, tempat, benda dan semua sumber daya lainnya dalam kehidupan seseorang sehingga mahasiswa mencapai efisiensi pribadi. Sehingga peran ganda sebagai mahasiswa dan pekerja dapat berjalan beriringan. Dari pengakuan informan tentang mahasiswa yang menerapkan strategi pembelajaran dalam hal memenuhi kebutuhan sendiri menunjukkan bahwa ada sejumlah mahasiswa yang sadar bahwa manajemen diri yang baik akan membawa keuntungan bagi mereka. Divisi waktu antara kuliah dan kegiatan lainnya tidak terganggu, jadwalnya menjadi terorganisir, kegiatan kemahasiswaan dan kegiatan lainnya tidak terganggu, bisa mengatur belajar, serta mampu mengatasi masalah yang dihadapi.
\end{abstract}

Self management means putting everything on a regular basis in life, in the use of time, choice, interests, activities, as well as in the physical and mental balance. It also means pushing self to get ahead, arrange all the elements of the personal, controlling potential willingness to accomplish 
good things, and develop various aspects of private life to make it more perfect. The first requirement for all students to achieve their education goals is self-motivation. Secondly, self organization is setting up as well as possible against the thought, effort, time, places, objects and all other resources in one's life so that students achieved personal efficiency. So that his dual role as students and workers can go hand in hand. From recognition of the informant about the students apply learning strategies in regards to qualify themselves indicate that there are a number of students who are aware of a good self management will bring a profit for them. Among them, the Division of time between lectures and other activities are not interrupted, his schedule became organized, as students and other activities are not disrupted, could set out the lesson, as well as being able to tackle the problems facing it.

Kata kunci: managemen diri, mahasiswa, peran ganda

\section{Pendahuluan}

Mahasiswa merupakan orang yang sedang menempuh pendidikan tinggi di perguruan tinggi, masa mahasiswa meliputi rentang umur dari 18/19 tahun sampai 24/25 tahun. Rentang umur itu masih dapat dibagibagi atas periode 18/19 tahun sampai 20/21 tahun, yaitu mahasiswa dari semester I sampai dengan semester IV; dan periode waktu 21/22 tahun sampai 24/25 tahun, yaitu mahasiswa dari semester V sampai dengan semester VIII (Winkel \& Hastuti, 2010: 157). Selain itu, mahasiswa juga masih dalam kategori remaja. Pada masa remaja satu tugas perkembangan yang perlu diupayakan, ialah diperolehnya suatu taraf identitas diri yang utuh (Basri, 2004: 70).

Mahasiswa memang memiliki keunikan tersendiri dibandingkan dengan siswa sekolah setingkat SD, SMP, maupun SMA (Pendidikan Dasar). Serta memiliki tempat tertinggi di jenjang pendidikan. Sistem 
pembelajaran pun juga berbeda sehingga menjadi salah satu faktor pendukung keunikan tersebut. Pada jenjang pendidikan tersebut, kita tidak pernah menemui istilah-istilah seperti IPK, SKS, Skripsi, Dosen, dan lain sebagainya. Lama waktu pembelajarannya pun tak sepadat sekolah-sekolah formal biasa, cukup dengan 3 hingga 4 jam perhari. Sementara itu, sering kali kita melihat mahasiswa itu seperti tidak pernah kuliah. Datang ke kampus, kuliah menunggu dosen, jika dosen tidak ada mahasiswa akan pulang atau ke kantin.

Masalah yang dihadapi mahasiswa yang melakukan kuliah sambil bekerja juga bermacam-macam, diantaranya: mengenai manajemen diri yaitu, bagaimana seorang mahasiswa tersebut bisa memposisikan diri secara tepat, sebagai mahasiswa yang tugasnya belajar dan sebagai pekerja/ karyawan yang mempunyai tugas untuk bekerja secara profesional. Bukan hanya itu saja, untuk mencapai tujuan pendidikan, yaitu lulus dari perguruan tinggi dan menjadi sarjana bermutu atau sesuai dengan ketentuan Peraturan Pemerintah 1990/30 tentang Pendidikan Tinggi menjadi "anggota masyarakat yang memiliki kemampuan akademik dan profesional yang dapat menerapkan, mengembangkan serta menciptakan ilmu pengetahuan, teknologi ataupun kesenian", setiap mahasiswa Indonesia harus mengatur dan mengelola dirinya secara sebaik-baiknya. Segenap langkah dan tindakan mengatur dan mengelola diri itu termasuk pengertian manajemen diri. Betapa pentingnya manajemen diri ini, tidak perlu dicarikan alasan-alasan pembenaran yang panjang-lebar. Karena dengan manajemen diri, mahasiswa bisa mendorong diri sendiri untuk maju, mengatur semua unsur potensi 
pribadi, mengendalikan kemauan untuk mencapai hal-hal yang baik, dan mengembangkan berbagai segi dari kehidupan pribadi agar lebih sempurna (Gie, 1995: 187-188).

Masalah selanjutnya yang biasa dihadapi oleh mahasiswa yaitu, mengenai gaya belajarnya, terkadang mahasiswa masih bingung menentukan dan menerapkan gaya belajar seperti apa yang cocok untuk dirinya, sebab gaya belajar setiap orang itu memiliki tipe yang berbedabeda. Ada yang lebih cenderung pada gaya belajar yang visual, auditori bahkan kinestetik. Sebab gaya belajar ataupun strategi belajar mahasiswa bisa menjadi salah satu faktor penentu prestasi belajarnya selama masa perkuliahannya. Karena sebagai mahasiswa yang mempunyai tugas ganda (belajar dan bekerja) tentunya sangat diperlukan penerapan gaya belajar yang tepat bagi dirinya. Sehingga mahasiswa tersebut bisa mencapai prestasi belajar sesuai dengan harapannya.

Di samping itu, sebagai mahasiswa juga harus mempunyai tujuan yang jelas. Tujuan adalah suatu keadaan akhir yang diinginkan. Seseorang yang bertindak tanpa tujuan sama saja dengan orang yang tidak tahu hendak pergi kemana. Yang hanya akan memboroskan waktu, energi dan biaya. Kalaupun berhasil sampai di tujuan maka itu hanya kebetulan saja, dan hasilnya pun akan dirasa kurang maksimal.

Hal tersebut adalah cara mahasiswa menyerap informasi dari apa yang diterima, tetapi seorang mahasiswa biasanya akan lebih condong pada salah satu dari ketiga gaya belajar yang telah disebutkan di atas. Apabila mahasiswa tersebut menyukai gaya belajar visual maka akan cenderung lebih suka belajar dengan cara melihat tulisan-tulisan, gambar 
yang memudahkan mereka dalam mengingat pelajaran seperti melihat grafik-grafik, film, video dan lain sebagainya. Lain halnya bagi seorang mahasiswa yang auditorial, maka akan lebih menikmati dimana harus mendengarkan penjelasan-penjelasan dari dosennya. Tapi apabila seorang mahasiswa itu cenderung kinestetik, maka akan lebih suka belajar apabila dilibatkan langsung secara fisik dalam proses pembelajaran.

\section{Metode Penelitian}

Penelitian ini merupakan penelitian lapangan (field research) pengambilan data-data yang terkumpul dari lapangan secara langsung. Jenis penelitian ini adalah penelitian kualitatif dengan pendekatan deskriptif, yaitu data yang terkumpul dijelaskan dengan kata-kata, atau kalimat, gambar dan bukan dengan angka (Moeleong, 2010: 4). Penelitian ini peneliti akan mendeskripsikan fenomena-fenomena yang terjadi pada mahasiswa Prodi PAI STAIN Salatiga.

\section{Pembahasan}

\section{Manajemen Diri Mahasiswa}

Makna manajemen diri secara sederhana, merujuk Kamus Besar Bahasa Indonesia (2001: 465) manajemen memiliki dua arti, yaitu: Penggunaan sumber daya secara efektif untuk mencapai sasaran; dan pimpinan yang bertanggung jawab atas jalannnya perusahaan dan organisasi. Kemudian, apa arti "diri” atau "saya"? Apakah yang kita sebut "diri" itu adalah akumulatif dari pikiran kita, seperti yang dikatakan 
David J. Schwarz bahwa "kita adalah apa yang kita pikirkan tentang diri kita". Yang kita sebut diri, pribadi, individu, adalah totalitas manusia sebagai perpaduan dari jasad dan ruhani,fisik yang bisa kita lihat dan sesuatu yang tak terlihat yang menggerakan fisik (hati; pikiran; jiwa). Diri adalah totalitas dari pemikiran, keinginan, dan gerakan kita dalam ruang dan waktu. Dengan kata lain,perpaduan antara intelektual, emosional, spiritual, dan fisik. Jadi, manajemen diri yang dimaksud adalah sebuah proses merubah "totalitas diri" yaitu intelektual, emosional, spiritual, dan fisik kita agar apa yang kita inginkan (sasaran) tercapai.

Manajemen diri dapat digunakan sebagai proses mencapai kemandirian (personal autonomy). Secara istilah manajemen diri yaitu menempatkan individu pada tempat yang sesuai untuk dirinya dan menjadikan individu layak menempati suatu posisi sehingga tercapai suatu prinsip laki-laki yang kapabel pada posisi yang tepat (yakni, menyediakan posisi untuk tiap-tiap individudan memposisikan tiap-tiap individu pada posisinya secara tepat). Jadi, pada dasarnya manajemen diri merupakan pengendalian diri terhadap pikiran, ucapan, dan perbuatan yang dilakukan, sehingga mendorong pada penghindaran diri terhadap hal-hal yang tidak baik dan peningkatan perbuatan yang baik dan benar. Manajemen diri adalah sebuah proses merubah "totalitas diri" baik itu dari segi intelektual, emosional, spiritual, dan fisik agar apa yang kita inginkan (sasaran) tercapai.

Mahasiswa merupakan suatu kelompok dalam masyarakat yang memperoleh statusnya karena ikatan di Perguruan Tinggi. Mahasiswa 
juga merupakan calon intelektual atau cendikiawan dalam suatu lapisan masyarakat yang sering kali kali syarat dengan berbagai predikat. Selanjutnya menurut Kamus Besar Bahasa Indonesia (2007: 696), mahasiswa adalah orang yang belajar di Perguruan Tinggi. Dari pendapat di atas bisa dijelaskan bahwa mahasiswa adalah status yang disandang oleh seseorang karena hubungannya dengan perguruan tinggi yang diharapkan menjadi calon-calon intelektual.

Kemudian Gie (1983: 160-161), berpendapat mengenai pengertian manajemen secara umum. Menurutnya, manajemen adalah segenap perbuatan menggerakkan sekelompok orang dan mengerahkan segala fasilitas dalam suatu usaha kerja sama untuk mencapai tujuan tertentu. Segenap perbuatan itu menurut rincian kami terdiri dari enam pola perbuatan yang berikut: Perencanaan, pembuatan keputusan, pembimbingan, pengkoordinasian, pengendalian, dan penyempurnaan.

Istilah manajemen diri merupakan istilah yang umum dipakai untuk menggambarkan kemampuan individu dalam mengorganisir kapasitas-kapasitas mental dalam mencapai tujuan (goal). Dalam kajian psikologi, istilah yang lebih tepat menggambarkan manajemen diri adalah self-regulation atau pengaturan diri adalah konsep yang dikemukakan oleh Albert Bandura untuk mendeskripsikan, pertama, Bandura berpendapat manusia dapat berfikir dan mengatur tingkah lakunya sendiri; sehingga mereka bukan semata-mata bidak yang menjadi objek pengaruh lingkungan. Sifat kausal bukan dimiliki sendirian oleh lingkungan, karena orang dan lingkungan saling mempengaruhi. Kedua, Bandura dalam sebuah jurnal menyatakan, self- 
regulation atau regulasi diri adalah suatu strategi yang digunakan oleh individu dalam mencapai goal atau tujuan tertentu. Bandura percaya, bahwa seorang individu akan menggunakan strategi tertentu di dalam regulasi dirinya. Lebih lanjut menurut Ormrod (2008: 125), kemampuan regulasi diri merupakan kemampuan yang dimiliki oleh setiap manusia, yang perlu dikembangkan dan diarahkan, karena perilaku yang dihasilkan oleh regulasi diri ini tidak bisa terjadi secara alamiah.

Menurut Gie (1995: 187), manajemen diri berarti segenap langkah dan tindakan mengatur, mengelola diri. Selain itu, manajemen diri juga bisa berarti mengatur semua unsur potensi pribadi, mengendalikan kemauan untuk mencapai hal-hal yang baik, dan mengembangkan berbagai segi dari kehidupan pribadi agar lebih sempurna. Dengan demikian maka manajemen diri yang dimaksud dalam penelitian ini mengacu pada bagaimana seorang mahasiswa berstatus kuliah sambil bekerja mengatur dirinya sebab mahasiswa mempunyai tanggung jawab dan peran ganda, yaitu sebagai mahasiswa yang tugasnya belajar dan sebagai karyawan/ pekerja yang tugasnya bekerja. Dengan pengaturan atau self-regulation yang baik maka diharapkan kedua peran tersebut bisa berjalan beriringan sehingga tidak mengabaikan salah satunya.

\section{Manajemen Diri untuk Pembentukan Kebiasaan Studi yang Baik}

Keterampilan pengaturan diri (Self Management) sangat diperlukan bagi mahasiswa. Manajemen diri ini menyangkut diri perorangan setiap mahasiswa dan mencerminkan seluruh kepribadiannya. Kepribadian orang adalah suatu segi yang terpenting dari sumber daya 
manusia. Kini telah diakui oleh semua pihak bahwa mutu sumber daya manusia merupakan hal terpenting dalam pembinaan suatu bangsa dan pembangunan negaranya. Kalau kualitas sumber daya manusia itu rendah, misalnya pribadinya cenderung nonproduktif (kata halus untuk 'malas') atau wataknya tidak mempunyai integritas (kejujuran), maka segala usaha pembangunan bangsa itu akan sia-sia (Gie, 1995: 187-190).

Begitu pentingnya manajemen diri, maka setiap mahasiswa harus bisa me-manage dirinya supaya bisa mencapai tujuan yang ingin dicapainya. Begitu juga dengan mahasiswa bersatatus kuliah sambil bekerja, supaya salah satu tugasnya sebagai pelajar ataupun karyawan/ pekerja tidak terabaikan, maka mahasiswa harus pintar me-manage dirinya dengan baik. Manajemen diri bagi mahasiswa mencakup sekurang-kurangnya 4 bentuk perbuatan yang berikut (Gie, 1995: 188191) yaitu: Pendorongan diri (self-motivation), penyusunan diri (selforganization), pengendalian diri (self-control) dan pengembangan diri (self-development).

Syarat pertama bagi setiap mahasiswa untuk mencapai tujuan pendidikannya ialah pendorongan diri (self-motivation). Ini ialah dorongan psikologis dalam diri seseorang yang merangsangnya sehingga mau melakukan berbagai kegiatan untuk mencapai tujuan yang didambakan. Suatu motivasi akan kuat kalau timbul dalam diri sendiri tanpa dorongan dari orang lain atau hal luar. Motivasi kuat untuk melakukan studi pada diri seseorang mahasiswa bersumber misalnya pada kesenangan membaca, keingintahuan terhadap pengetahuan baru, dan hasrat pribadi untuk maju. 
Pendorongan diri yang kuat akan melahirkan minat besar untuk melakukan studi dengan sepenuh kemampuan. Pada kelanjutannya minat seseorang mahasiswa yang besar akan mendatangkan hasil studi memuaskan, karena ia dapat melakukan konsentrasi, tidak terganggu perhatiannya oleh hal lain, mudah memahami bahan pelajarannya, mampu studi jangka waktu yang lama, dan bahkan memperoleh kesenangan batin dari studi itu karena bertambahnya pengetahuan. Hasil studi yang memuaskan itu pada akhirnya akan mengobarkan motivasi diri yang lebih kuat lagi. Dengan demikian, terjadilah suatu mata rantai lingkaran yang saling memacu secara menguntungkan dalam pelaksanaan studi.

Bentuk perbuatan kedua dalam manajemen diri ialah penyusunan diri (self-organization). Ini ialah pengaturan sebaik-baiknya terhadap pikiran, tenaga, waktu, tempat, benda, dan semua sumber daya lainnya dalam kehidupan seseorang mahasiswa sehingga tercapai efisiensi pribadi. Efisiensi pribadi adalah perbandingan terbaik antara setiap kegiatanhidup pribadi mahasiswa dengan hasil yang diinginkan. Misalnya, mahasiswa yang perlu mengerahkan segenap tenaga ingatannya untuk menghafal bahan-bahan pelajaran yang demikian banyak (sampai delapan mata pelajaran setiap semester). Pada pokoknya penyusunan diri atau pengorganisasian diri adalah merencanakan, mengatur, dan mengurus agar segala hal dalam diri sendiri atau yang menyangkut diri pribadi dapat berlangsung secara tertib, lancar, dan mudah. 
Pengendalian diri atau self-control ialah perbuatan membina tekad untuk mendisiplin kemauan, memacu semangat, mengikis keseganan, dan mengerahkan energi untuk benar-benar melaksanakan apa yang harus dikerjakan dalam studi. Rencana belajar, program studi, dan jadwal kegiatan akademik lainnya yang telah ditetapkan tidak ada gunanya kalau kemudian seseorang mahasiswa tidak dapat mengendalikan tekadnya sampai mengerahkan engerginya untuk menyelesaikan. Melatih kontrol diri itu harus sungguh-sungguh diusahakan dari waktu ke waktu oleh setiap mahasiswa yang ingin menjadi mahasiswa yang unggul. Selfcontrol merupakan salah satu persyaratan yang tidak kalah pentingnya ketimbang self-motivation dan self-organization untuk mencapai sukses dalam studi.

Bentuk manajemen diri terakhir ialah pengembangan diri (selfdevelopment). Ini adalah perbuatan menyempurnakan atau meningkatkan diri sendiri dalam berbagai hal. Pengembangan diri yang lengkap dan penuh mencakup segenap sumber daya pribadi dalam seorang mahasiswa. Pendorongan diri, penyusunan diri, dan pengendalian diri hendaknya terutama ditujukan untuk membentuk dan mengembangkan berbagai kebiasaan studi yang baik pada diri mahasiswa.

\section{Aspek-Aspek Manajemen Diri}

Mahasiswa yang berstatus kuliah sambil bekerja memang harus memiliki pengaturan diri yang baik. Sebab setiap peran yang harus dijalani individu pasti ada tanggung jawab yang harus dipenuhi. Jika 
individu dihadapkan oleh banyak peran dalam hidupnya, maka kualitas pribadi individu tersebut akan semakin berkembang.

Dalam firman Allah SWT pun sudah dijelaskan bahwa kita sebagai manusia harus mampu mengatur diri dengan baik, seperti yang terdapat dalam surat al-Hasyr ayat 18 di bawah ini:

Hai orang-orang yang beriman, bertakwalah kepada Allah dan hendaklah Setiap diri memperhatikan apa yang telah diperbuatnya untuk hari esok (akhirat); dan bertakwalah kepada Allah, Sesungguhnya Allah Maha mengetahui apa yang kamu kerjakan (Departemen Agama RI, 2004: 548).

Dari ayat tersebut kita bisa melihat bahwa Allah pun menyuruh kita untuk mengatur diri serta selalu memperhatikan perilaku-perilaku atau pekerjaan yang kita lakukan. Oleh sebab itu, sebagai mahasiswa berstatus kuliah sambil bekerja, harus bisa menentukan prioritas mana yang diutamakan terlebih dahulu, dan selalu memperhatikan terhadap tanggung jawab yang telah ia pilih yaitu, belajar dan bekerja.

Standar dan tujuan ditetapkan bagi diri mahasiswa sendiri, dan cara mahasiswa memonitor dan mengevaluasi proses-proses kognitif dan perilaku diri sendiri, dan konsekuensi-konsekuensi yang ditentukan sendiri untuk setiap kesuksesan dan kegagalan semuanya merupakan aspek-aspek pengendalian diri (self-regulation). Jika pemikiran dan tindakan berada di bawah kontrol sendiri, bukan kontrol orang lain, dan kondisi di sekitar diri sendiri, maka seseorang itu merupakan individuindividu yang mengatur diri. Mengatur diri menurut mempunyai arti menempatkan segala sesuatunya teratur dalam hidup, dalam penggunaan 
waktu, pilihan, minat, beraktivitas, serta dalam keseimbangan fisik dan mental.

Idealnya sebagai mahasiswa yang berstatus kuliah sambil bekerja mempunyai pengaturan diri yang baik, supaya antara tugas belajar dan bekerjanya bisa berjalan beriringan dan tidak ada yang terabaikan. Untuk itu seorang mahasiswa tersebut sebaiknya bisa mengatur perilakunya sendiri, mengatur pembelajaran sendiri dan bisa melakukan pemecahan masalah sendiri seperti yang dikemukakan oleh (Ormrod, 2009: 30-42) dengan uraian di bawah ini: Self-regulating behavior yaitu Ketika berperilaku dalam cara tertentu dan mengamati bagaimana lingkungan bereaksi memberi pnguatan pada beberapa perilaku dan menghukum atau mencegah perilaku yang lain, mulai membedakan antara respons yang diinginkan dan respons yang tidak diinginkan. Ketika seseorang mengembangkan suatu pemahaman mengenai respons-respons mana yang sesuai dan mana yang tidak sesuai (setidaknya bagi diri sendiri), itu berarti seseorang semakin mengontrol dan memonitor perilakunya sendiri. Dengan kata lain, seseorang terlibat dalam perilaku yang diatur diri sendiri (self-regulated behavior). Self-regulated learning artinya Para ahli kognitif sosial dan juga psikologi kognitif mulai menyadari bahwa untuk menjadi pembelajar yang benar-benar efektif, siswa harus terlibat dalam beberapa aktivitas mengatur diri (self-regulating activities). Dalam kenyataan, tidak hanya siswa yang harus mengatur perilakunya sendiri melainkan juga setiap orang harus mengatur proses-proses mentalnya sendiri. Secara khusus, pembelajaran yang diatur sendiri (self-regulated learning) mencakup proses-proses sebagai berikut: penetapan tujuan 
(goal setting), perencanaan, motivasi diri, kontrol atensi, penggunaan strategi belajar yang fleksibel, memonitor diri, mencari bantuan yang tepat, evaluasi diri. Self-regulated problem solving adalah Mengarahkan usaha sendiri secara efektif untuk memecahkan masalah-masalah yang kompleks yang lazim disebut pemecahan masalah yang diatur sendiri (self-regulated problem solving), melibatkan banyak komponen yang sama dalam pembelajaran yang diatur sendiri (self-regulated learning): penetapan tujuan, motivasi diri, kontrol atensi, evaluasi diri dan sebagainya.

Pemecahan masalah yang bersifat self-regulated itu penting tidak hanya untuk memecahkan masalah-masalah akademik saja, melainkan juga masalah-masalah sosial. Langkah pemecahan masalah itu sebagai berikut: Perjelas masalahnya, identifikasi beberapa solusi yang mungkin, prediksi konsekuensi-konsekuensi yang mungkin dari setiap solusi, pilih solusi yang terbaik, identifikasi langkah-langkah yang dibutuhkan untuk menjalankan solusi, jalankan langkah-langkah itu, dan evaluasi hasilhasilnnya.

\section{Karakteristik Individu dengan Manajemen Diri yang Baik}

Menurut Ormrod (2009: 54) dalam sebuah jurnal ada beberapa karakteristik siswa yang memiliki kemampuan regulasi diri yang baik: Menetapkan standar dan tujuan yang ditetapkan: menunjukkan adanya standar dan tujuan tertentu yang dianggap bernilai dan yang menjadi arah dan sasaran perilaku. Pengaturan emosi: proses selalu memeriksa atau secara sengaja mengubah perasaan yang mungkin mengarah pada 
perilaku yang kontraproduktif. Melakukan instruksi diri: instruksi yang seseorang berikan kepada dirinya sendiri sambil melakukan suatu perilaku yang kompleks. Melakukan self-monitoring: menujukkan kemampuan individu dalam mengamati dan mencatat perilaku sendiri. Melakukan evaluasi diri: merupakan penilaian terhadap performa atau perilaku sendiri. Membuat kontigensi yang ditetapkan sendiri: menunjukkan adanya penguatan dan hukuman yang ditetapkan sendiri yang menyertai perilaku.

\section{Faktor-faktor yang Mempengaruhi Regulasi Diri}

Ada dua faktor yang mempengaruhi regulasi diri seseorang, yakni faktor eksternal dan faktor internal. Faktor eksternal mempengaruhi regulasi diri setidaknya dalam dua cara Feist \& Feist dalam sebuah jurnal (2010): Memberikan individu suatu standar untuk mengevaluasi perilaku kita. Seperti, faktor lingkungan yang mempengaruhi standar individual untuk mengevaluasi performa diri. Mempengaruhi regualsi diri dengan menyediakan cara untuk mendapatkan penguatan. Misalnya, dukungan dari lingkungan untuk memberikan penguatan terhadap hasil kerja seseorang.

Lebih jauh, menurut Bandura dalam sebuah jurnal menyatakan, terdapat tiga faktor internal dalam regulasi diri: Self-observation: perilaku manusia umumnya bervariasi, tergantung dari pengamatan yang dilakukan oleh individu itu sendiri. Disini, setiap individu memiliki sudut pandang yang berbeda-beda dari individu yang lainnya. Evaluasi diri terhadap kemajuan atau Judgemental process: setelah melakukan 
pengamatan, individu akan melakukan penilaian tentang perilakunya. Apakah perilkunya dinilai sudah memuaskan atau belum. Penilaian yang dilakukan oleh individu itu sendiri, didasarkan oleh standar personal individu. Apabila seseorang menaruh nilai yang tinggi dalam pencapaian tujuannya, maka individu tersebut akan melakukan banyak usaha tertentu untuk mencapai tujuan atau kesuksesannya (Feist \& Feist). Self-reaction atau self-responded: adanya bentuk reward atau punishment terhadap pribadi.

\section{Keterampilan Dasar untuk Belajar yang Efektif}

Kosentrasi adalah bagian dari ketrampilan awal dalam belajar, kebanyakan orang menganggap bahwa konsentrasi adalah pekerjaan berat dan sangat sulit dilakukan. Seseorang memiliki suatu keyakinan bahwa hal tersebut susah untuk dilakukan. Padahal kalau seseorang menyenangi sesuatu, sebagai contoh menonton konser musik band favoritnya atau film di bioskop, maka orang itu akan dapat berkonsentrasi menikmati pertunjukan yang berlangsung lebih dari dua jam. Ternyata dapat berkonsentrasi cukup lama jika seseorang melakukan sesuatu yang disenanginya. Inilah pola pikir pertama yang harus dikembangkan untuk belajar berkonsentrasi.

Hal kedua adalah bahwa mengembangkan daya konsentrasi sama halnya dengan mengembangkan dan menguatkan otot-otot tubuh. Seseorang perlu latihan teratur dan terus menerus. Salah satu teknik untuk mengembangkan daya konsentrasi adalah teknik kontemplasi. Kontempalsi adalah suatu teknik menggunakan pikiran kita seperti 
sebuah lampu senter (Searchlight) untuk mencari dan menemukan informasi baru. Untuk melatihnya, perlu dilakukan setiap hari (sedikitnya 5 menit sampai maksimum 10 menit per latihan). Caranya dimulai dengan fokus terhadap apa yang ingin kita ketahui.

Jika sudah bisa bertahan konsentrasi 10 menit, tingkatkan kemampuan dengan berlatih langsung membaca sebuah buku 10-20 menit. Lakukan setiap hari sampai daya tahan konsentrasi meningkat sedikit demi sedikit.

Membuat peta pikiran (mind mapping), teknik ini merupakan cara untuk meringkas suatu tema atau pokok pikiran yang ada dalam buku. Pertama, diawali dengan menuliskan tema pokok di tengah-tengah halaman kertas kosong. Kemudian seperti pohon dengan cabang dan ranting dikembangkan tema pokok menjadi sub tema di sekelilingnya dengan dihubungkan memakai garis seperti jari-jari roda. Relaksasi, menggunakan teknik relaksasi seseorang dapat meningkatkan kemampuan kita untuk belajar dengan lebih cepat, efektif dan efisien (Sembel, 2003: 122-123).

Tiga faktor penting meningkatkan kemampuan belajar, Sembel (2003: 123-124), ada tiga faktor penting dalam penguasaan keterampilan untuk belajar: pertama adalah pola pikir dan sikap (mindset and attitude) seseorang terhadap belajar. Seseorang harus memiliki hasrat (desire) dan kecintaan (passion) yang dalam terhadap nilai-nilai untuk terus belajar dan mengembangkan diri. Belajar tidak hanya sekedar melalui pendidikan formal semata, tetapi dalam setiap aspek kehidupan harus senantiasa mengembangkan sikap belajar. Sikap mau membaca, 
mendengar, mau mengerti dan mau belajar dari orang lain merupakan sikap yang perlu senantiasa dikembangkan jika seseorang ingin memperbaiki diri.

Faktor kedua dalam meningkatkan keterampilan untuk belajar adalah kemampuan seseorang untuk mendayagunakan kekuatan pikiran yang dimilikinya (terutama pikiran bawah sadar-subconcious mind) untuk mempercepat proses belajar (accelerated learning). Pikiran bawah sadar merupakan kekuatan yang luar biasa jika dapat mengoptimalkan potensinya. Sering kali orang melupakan bahwa anugerah yang terindah dan terbesar yang diberikan Tuhan, yaitu kemampuan pikiran yang dimilikinya. Hal inilah yang membedakan manusia dengan ciptaanNya yang lain.

Hal yang paling mudah dilakukan untuk mengembangkan keterampilan belajar adalah dengan banyak membaca. Meluangkan waktu sedikitnya satu jam sehari untuk membaca buku merupakan kebiasaan yang baik. Banyak sekali metode untuk meningkatkan kecepatan membaca (speed reading) maupun pemahaman (comprehension) terhadap isi dari suatu buku. Keterampilan inilah yang amat diperlukan untuk meningkatkan daya serap dan kecepatan seseorang dalam membaca sebuah buku. Selain membaca, meningkatkan kemampuan dapat diperoleh melalui seminar, pelatihan maupun mendengarkan kaset-kaset motivasi.

Faktor ketiga dalam meningkatkan kemampuan belajar adalah disiplin diri dan kegigihan (self discipline and persistence). Tanpa kedua hal ini maka pelajar hanyalah kegiatan yang sifatnnya tergantung suasana 
hati (mood) dan tidak dapat mencapai keunggulan (excellence) hanya dengan belajar setengah hati. Ada pepatah yang mengatakan "Your Habits will Determine Your Future". Miliki kebiasaan belajar, dan mulai langkah pertama anda. Proses mengubah kebiasaan sangat ditentukan oleh kedisiplinan diri dan kegigihan yang dimiliki seseoran, sehingga setelah melakukannya dalam periode waktu tertentu, hal tersebut tidak lagi menjadi beban tetapi telah menjadi kebutuhan.

\section{Prestasi Belajar}

Menurut Agus Suprijono (2011: 7) Prestasi belajar adalah perubahan perilaku secara keseluruhan bukan hanya salah satu aspek potensi kemanusiaan saja. Artinya, hasil pembelajaran yang dikategorisasi oleh pakar pendidikan sebagaimana tersebut di atas tidak dilihat secara fragmentaris atau terpisah melainkan secara komprehensif. Sedangkan menurut Purwanto (2011: 54) Prestasi belajar adalah perubahan perilaku yang terjadi setelah mengikuti proses belajar mengajar sesuai dengan tujuan pendidikan.

Dari kedua teori di atas dapat penulis simpulkan bahwa prestasi belajar adalah suatu hasil akhir yang telah dicapai oleh seseorang setelah melakukan proses belajar yang menghasilkan perubahan-perubahan tersebut dapat diperinci sebagai berikut: Tingkah laku, sistem nilai, perbendaharaan konsep, dan kekayaan informasi. 


\section{Tes Prestasi Belajar}

Tes prestasi belajar dilakukan untuk mengukur hasil belajar yakni sejauh mana perubahan perilaku yang diinginkan dalam tujuan pembelajaran telah dapat dicapai oleh para mahasiswa. Dalam mengukur hasil belajar, mahasiswa didorong untuk menunjukkan penampilan maksimalnya. Dari penampilan maksimal yang ditunjukkan dalam jawaban atas tes hasil belajar dapat diketahu penguasaan siswa terhadap materi yang diajarkan dan dipelajari. Tes hasil belajar dapat dibagi menjadi empat macam yaitu: Pertama, tes formatif dimaksudkan sebagai tes yang digunakan untuk mengetahui sejauh mana siswa telah terbentuk setelah mengikuti proses belajar mengajar (Purwanto, 2011: 67). Tes formatif dalam praktik pembelajaran dikenal sebagai ulangan harian. Kedua, Tes Sumatif dimaksudkan sebagai tes yang digunakan untuk mengetahui penguasaan mahasiswa atas semua jumlah materi yang disampaikan dalam satuan waktu tertentu seperti catur wulan atau semester (Purwanto, 2011: 68). Dalam praktik pengajaran tes sumatif dikenal sebagai ujian akhir semester atau catur wulan tergantung satuan waktu yang digunakan untuk menyelesaikan materi. Ketiga, Tes Diagnostik adalah tes hasil belajar yang digunakan sebagai dasar untuk melakukan evaluasi diagnostik (Purwanto, 2011: 69). Dalam evaluasi diagnostik, tes hasil belajar digunakan untuk mengidentifikasi mahasiswa-mahasiswa yang mengalami masalah dan menelusuri jenis masalah yang dihadapi. Berdasarkan pemahaman mengenai mahasiswa bermasalah dan masalahnya maka guru dapat mengusahakan pemecahan masalah yang tepat sesuai dengan masalahnya. Keempat, Tes 
penempatan adalah pengumpulan data tes hasil belajar yang diperlukan untuk menempatkan mahasiswa dalam kelompok mahasiswa sesuai dengan minat dan bakatnya (Purwanto, 2011: 69). Dalam praktik pembelajaran penempatan merupakan hal yang banyak dilakukan.

\section{Faktor yang Mempengaruhi Prestasi Belajar}

Menurut Djamarah (2011: 177) faktor-faktor yang mempengaruhi prestasi belajar adalah: Unsur dari luar meliputi lingkungan alami, lingkungan sosial budaya, dan instrumental meliputi kurikulum, program, sarana dan fasilitas serta dosen. Sedangkan unsur dari dalam meliputi aspek fisiologi dan psikologis antara lain: kondisi fisiologis, kondisi panca indera, minat, kecerdasan, bakat, motivasi dan kemampuan kognitif.

Jadi karena pengaruh faktor-faktor tersebut di ataslah, muncul mahasiswa-mahasiswa yang high achievers (berprestasi tinggi) dan under achievers (berprestasi rendah) atau gagal sama sekali (Purwanto, 2011: 129). Kegiatan belajar dilakukan oleh setiap siswa, karena melalui belajar mereka memperoleh pengalaman dari situasi yang dihadapinya. Dengan demikian belajar berhubungan dengan perubahan dalam diri individu sebagai hasil pengalamannya di lingkungan.

Secara global menurut Syah (2011: 129), faktor-faktor yang mempengaruhi belajar mahasiswa dapat kita bedakan menjadi tiga macam, yakni: 


\section{Faktor Internal (Faktor dari dalam Mahasiswa)}

Faktor yang berasal dari dalam diri mahasiswa sendiri meliputi dua aspek yakni: Pertama, aspek fisiologis adalah kondisi umum jasmani dan tonus (tegangan otot) yang menandai tingkat kebugaran organorgan tubuh dan sendi-sendinya, dapat mempengaruhi semangat dan intensitas mahasiswa dalam mengikuti pelajaran. Kondisi organ tubuh yang lemah dapat menurunkan kualitas ranah cipta (kognitif) sehingga materi yang dipelajarinya pun kurang atau tidak membekas. Kedua, aspek psikologis adalah Banyak faktor yang termasuk aspek psikologis yang dapat mempengaruhi kuantitas dan kualitas perolehan belajar mahasiswa. Namun, diantara faktor-faktor rohaniah mahasiswa yang pada umumnya dipandang lebih esensial itu adalah sebagai berikut:

\section{Tingkat Kecerdasan atau Intelegensi Mahasiswa}

Intelegensi pada umumnya dapat diartikan sebagai kemampuan psiko-fisik untuk mereaksi rangsangan atau menyesuaikan diri dengan lingkungan dengan cara yang tepat. Jadi, intelegensi sebenarnya bukan persoalan otak saja, melainkan juga kualitas organ-organ tubuh lainnya. Akan tetapi, memang harus diakui bahwa peran otak dalam hubungan dengan intelegensi manusia lebih menonjol daripada peran organ-organ tubuh lainnya, lantaran otak merupakan menara pengontrol hampir seluruh aktifitas manusia (Syah, 2011: 121).

Tingkat kecerdasan atau intelegensi (IQ) siswa tak dapat diragukan lagi, sangat menentukan tingkat keberhasilan belajar mahasiswa. Ini bermakna, semakin tinggi kemampuan intelegensi 
seorang Mahasiswa maka semakin besar peluangnya untuk memperoleh sukses.

\section{Sikap Mahasiswa}

Sikap adalah gejala internal yang berdimensi afektif berupa kecenderungan untuk mereaksi atau merespon (response tendency) dengan cara yang relatif tetap terhadap objek, orang, barang, dan sebagainya, baik secara positif maupun negatif (Syah, 2011: 132).

Sikap merupakan faktor psikologis yang akan mempengaruhi belajar. Dalam hal ini sikap yang akan menunjang belajar seseorang ialah sikap poitif (menerima) terhadap bahan atau pelajaran yang akan dipelajari, terhadap dosen yang mengajar dan terhadap lingkungan tempat dimana ia belajar seperti: kondisi kelas, teman-temannya, sarana pengajaran dan sebagainya.

\section{Bakat Mahasiswa}

Secara umum, bakat (aptitude) adalah kemampuan potensial yang dimiliki seseorang untuk mencapai keberhasilan pada masa yang akan datang. Dengan demikian, sebetulnya setiap orang mempunyai bakat dalam arti berpotensi untuk mencapai prestasi sampai ketingkat tertentu sesuai dengan kapasitas masing-masing. Jadi, secara umum bakat mirip dengan intelegensi. Itulah sebabnya seorang anak yang berintelegensi sangat cerdas (superior) atau cerdas luar bisa (very superior) disebut juga sebagai talented child, yakni anak berbakat (Syah, 2011: 133). 


\section{Minat Mahasiswa}

Secara sederhana minat (interest) berarti kecenderungan dan kegairahan yang tinggi atau keinginan yang besar terhadap sesuatu. Minat seperti yang dipahami dan di pakai oleh orang selama ini dapat mempengaruhi kualitas pencapaian hasil belajar mahasiswa dalam bidang studi tertentu (Syah, 2011: 134).

\section{Motivasi Mahasiswa}

Pengertian dasar motivasi adalah keadaan internal organisme baik ataupun hewan yang mendorongnya untuk berbuat sesuatu (Syah, 2011: 134). Dalam perkembangan selanjutnya, motivasi dapat dibedakan menjadi dua macam, yaitu: motivasi intrinsik dan motivasi ekstrinsik. Dalam perspektif kognitif, motivasi yang lebih signifikan bagi mahasiswa adalah motivasi intrinsik karena lebih murni dan langgeng serta tidak bergantung pada dorongan atau pengaruh orang lain.

\section{Faktor Eksternal (Faktor dari Luar Diri Mahasiswa)}

Terdiri dari faktor lingkungan dan faktor instrumental sebagai berikut: Pertama, Faktor-faktor lingkungan mahasiswa ini dapat dibagi menjadi dua bagian yaitu: faktor lingkungan alami/non sosial dan faktor lingkungan sosial budaya. Yang termasuk faktor lingkungan non sosial/alami ini ialah seperti: keadaan suhu, kelembaban udara, waktu (pagi, siang, malam), tempat letak gedung kampus, dan sebagainya. Faktor lingkungan sosial budaya baik berwujud manusia dan representasinya termasuk budayanya akan mempengaruhi proses dan 
hasil belajar mahasiswa. Kedua, Faktor-faktor Instrumental ini terdiri dari kurikulum, program, sarana dan fasilitas, serta dosen. Setiap sekolah mempunyai tujuan yang akan dicapai. Tujuan tentu saja pada tingkat kelembagaan. Dalam rangka melicinkan kearah itu diperlukan kelengkapan dalam berbagai bentuk dan jenisnya. Semuanya dapat diberdayagunakan menurut fungsi masing-masing kelengkapan sekolah. Kurikulum dapat dipakai oleh dosen dalam merencanakan program pengajaran. Program sekolah dapat dijadikan acuan untuk meningkatkan kualitas belajar mengajar. Sarana dan fasilitas yang tersedia harus dimanfaatkan sebaik-baiknya agar berdaya guna dan berhasil guna bagi kemajuan belajar mahasiswa di kampus (Djamarah, 2011: 180).

\section{Faktor Pendekatan Belajar}

Faktor pendekatan belajar yakni jenis upaya belajar mahasiswa yang meliputi strategi dan metode yang digunakan mahasiswa untuk melakukan kegiatan mempelajari materi-materi pelajaran (Syah, 2011: 129). Strategi dan metode dalam hal ini berarti seperangkat langkah/cara operasional yang direkayasa sedemikian rupa untuk memecahkan masalah atau mencapai tujuan belajar tertentu. Dalam hal metode pembelajaran tentang keberhasilan dalam mengajar, Allah berfirman (Q.S An-Nahl, 16: 125)

"Serulah (manusia) kepada jalan Tuhan-mu dengan hikmah dan pelajaran yang baik dan bantahlah mereka dengan cara yang baik. Sesungguhnya Tuhanmu dialah yang lebih mengetahui tentang siapa yang tersesat dari jalan-Nya dan dialah yang lebih mengetahui orang-orang yang mendapat petunjuk"(Depag RI, 2004: 235). 
Dari semua faktor di atas, dalam penelitian kali ini akan diarahkan pada faktor instrumental yang di dalamnya dosen profesional itu akan ditunjukan. Faktor-faktor di atas saling mempengaruhi satu sama lain. Misalnya: Seorang mahasiswa yang conserving terhadap ilmu pengetahuan biasanya cenderung mengambil pendekatan yang sederhana dan tidak mendalam. Sebaliknya seorang mahasiswa yang memiliki kemampuan intelegensi yang tinggi (faktor Internal) dan mendapat dorongan positif dari orang tua atau dosennya (faktor eksternal) akan lebih memilih pendekatan belajar yang lebih mementingkan kualitas hasil belajar.

Akibat pengaruh faktor-faktor tersebut diatas muncul mahasiswamahasiswa yang berprestasi tinggi, rendah atau gagal sama sekali. Dalam hal ini seorang dosen yang memiliki kompetensi yang baik dan profesional diharapkan mampu mengantisipasi kemungkinankemungkinan munculnya mahasiswa yang menunjukkan gejala kegagalan dengan berusaha mengetahui dan mengatasi faktor-faktor yang menjadi penghambat proses belajar mahasiswa.

\section{Cara Membangun Kepercayaan Diri guna Meningkatkan Prestasi} Akademik Mahasiswa

Rasa percaya diri dapat dikembangkan dengan berbagai cara. Adapun cara-cara itu antara lain: Pertama, menjadikan hati ridha merupakan langkah awal dalam membina kepercayaan diri, karena menjadikan hati ridha adalah tindakan yang smart dan membuat diri mudah menerima berbagai kemungkinan yang terjadi dalam hidup ini. 
Kedua, bersyukur dan tawakal: kenikmatan yang telah diperoleh tetap disyukuri. Apabila terdapat suatu permasalahan yang menurut kita sulit maka usaha yang harus diambil adalah bertawakal kepada Allah (Sholikin, 2005: 128). Ketiga, mengenali diri sendiri: pengenalan diri bisa dilakukan melalui penelusuran terhadap apa yang bisa dan apa yang tidak bisa, apa yang diinginkan dan yang tidak diinginkan. Setelah mengerti benar kondisi diri, maka dengan sendirinya kita akan merasa yakin(Al-Asyhar, 2005: 73). Keempat, mencintai orang lain: Bergaul bersama mereka dengan luwes akan menjadikan kita orang yang dicintai dan dipercaya. Hendaklah berusaha mengetahui kebutuhan orang lain. Kemudian berusaha memberikan bantuan kepada mereka dengan tulus, karena amal yang baik ini sesungguhnya akan menambah rasa percaya diri. Kelima, menjauhi pikiran-pikiran dan perasaan negatif yang merusak kepribadian (gelisah, takut dan merasa gagal), yaitu berusaha untuk menghilangkan pikiran dan perasaan negatif yang dapat menghambat cita-cita. Keenam, bergaullah dengan orang yang sukses dan percaya diri dan belajarlah dalam bertindak jika kita ingin seperti mereka. Ketujuh, tentukan tujuan yang hendak dicapai dalam waktu dekat dengan memperhatikan tujuan tersebut adalah suatu yang nyata, dan mungkin untuk diwujudkan. Ketika tujuan itu sesuai dengan tercapai, maka akan bertambah kepercayaan kepada diri sendiri (Masykur, 2008: 206). Kedelapan, ikuti berbagai kegiatan organisasi: Kita merasa sulit memahami tindakan orang lain dalam keadaan tertentu kalau tindakan itu tidak seperti apa yang mungkin dilakukan sendiri. Mereka mungkin bertindak dengan cara yang tampaknya asing sama sekali bagi kita, dan 
keculai kalau kita mengerti bahwa keputusan mereka adalah hasil rangkaian keyakinan yang berbeda dengan apa yang kita yakini, maka hal itu bisa mengakibatkan timbulnya salah pengertian yang serius.

Inilah perlunya mengikuti berbagai kegiatan semacam organisasi. Akan banyak karakter orang yang ada di dalamnya sehingga membuat kita terangsang dan terpacu untuk bisa mengendalikan dan menyesuaikan diri. Semakin banyak berlatih melakukan itu semua dengan berbagai aktivitas dan kegiatan, pengendalian diri akan semakin baik. Begitu pula dengan sikap rasa percaya diri yang akan semakin tumbuh seiring dengan banyaknya orang di sekeliling kita yang juga memiliki rasa percaya diri (Mastuti, 2008: 69). Sebenarnya masih banyak cara dalam membangun rasa percaya diri. Namun dari uraian di atas telah memberikan pengetahuan tentang cara-cara membangun kepercayaan diri guna meningkatkan prestasi akademik dalam pendidikan Islam.

\section{Kesimpulan}

Manajemen diri, gaya belajar dan prestasi belajar mahasiswa bisa diartikan dengan apabila mahasiswa mampu mengatur diri dengan baik, mengenali dan menerapkan gaya belajar yang ada pada dirinya serta bisa mengimplementasikan pada belajarnya, selain itu kepercayaan diri perlu dibangun dengan menjadikan hati ridha, bersyukur dan tawakal, mengenali diri sendiri, mencintai orang lain, menjauhi pikiran-pikiran dan perasaan negatif yang merusak kepribadian (gelisah, takut dan merasa gagal), bergaullah dengan orang yang sukses dan percaya diri, tentukan tujuan yang hendak dicapai dalam waktu dekat dan ikuti 
berbagai kegiatan organisasi. Maka mahasiswa akan memperoleh hasil yang baik. Sebaliknya, jika mahasiswa tidak bisa mengatur diri, tidak bisa menerapkan gaya belajar yang sesuai dan tidak percaya diri akan berakibat tidak baik bagi prestasi akademiknya.

\section{Daftar Pustaka}

Al-Azhar, Thobieb, Sufi Funki Menjadi Remaja Gaul yang Saleh, Jakarta, Gema Insani, 2005.

Depag RI. 2004. Al-Qur'an dan terjemah New Cordova. Jawa Barat: Syaamil Qur'an.

Departemen Pendidikan dan kubudayaan/Pusat Bahasa. 2001. Kamus Besar Bahasa Indonesia(Edisi ke-3). Jakarta: Balai Pustaka.

Departemen Pendidikan Nasional. 2007. Kamus Besar Bahasa Indonesia. Jakarta: Balai Pustaka.

Djamarah, Syaiful Bahri, 2011. Psikologi Belajar, Jakarta: PT. Rineka Cipta

Feist, Jess\& Gregory J. Feist. 2010. Teori Kepribadian,Terj.Handriatno. Jakarta: Salemba Humanika.

Gie, The Liang. 1983. Garis Besar Estetik (Filsafat Keindahan). Yogyakarta: Supersukses.

Gie, The Liang. 1995. Cara Belajar yang Efisien; Sebuah Buku Pegangan untuk Mahasiswa Indonesia, jilid II. Yogyakarta: Liberti.

Ormrod, Jeanne. Ellis. 2008. Educational Psychology Developing Learners Sixth Edition (Psikologi Pendidikan Jilid 2 Edisi ke 6). Alih Bahasa: Amitya Kumara. Jakarta: Erlangga.

Mastuti, Indari, 50 Kiat Percaya Diri, Jakarta: Hi-Fest Publishing, 2008.

Nuzhif Masykur, Muhammad, Living Smart, Yogyakarta: Pro-U, 2007.

Purwanto, 2011. Evaluasi Hasil Belajar, Yogyakarta: Pustaka Pelajar

Rivai dan Basri. 2004. Manfaat Penilaian Kinerja. Jurnal http://jurnalsdm.blogspot.com/2004/04/penilaian-kinerja-karyawandefinisi.html. diakses 14 Januari 2015.

Sembel, Dantje T. 2003. Entomologi Kedokteran, Yogyakarta: Andi.

Solikin, Bangkit dong Sobat, Jakarta, Gema Insani, 2005.

Syah, Muhibbin. 2011. Psikologi Pendidikan, Bandung: Remaja Rosdakarya 
Mudarrisa: Jurnal Kajian Pendidikan Islam, Vol. 6, No.2, Desember 2014: 221-250

Suprijono, Agus. 2011. Cooperative Learning Teori dan Aplikasi PAIKEM, Yogyakarta: Pustaka pelajar

Winkel, W.S. \& M.M, Sri Hastuti. 2010. Bimbingan dan Konseling di Institusi Pendidikan. Yogjakarta: Media Abadi 